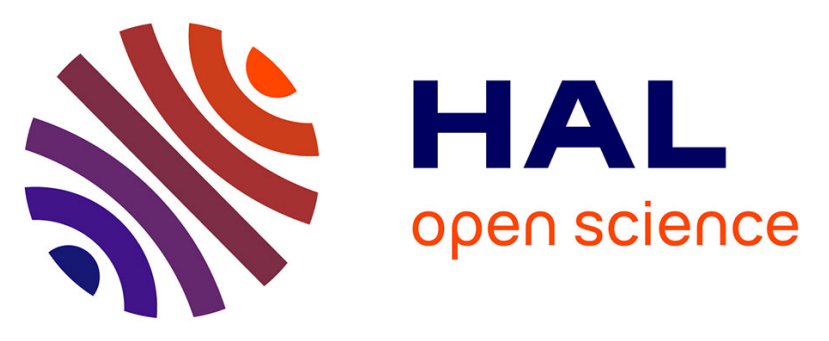

\title{
Structure-based virtual screening to get news scaffold inhibitors of the Ser/Thr Protein Kinase PknB from Mycobacterium tuberculosis
}

Antonio Coluccia, Giuseppe La Regina, Nathalie Barilone, Maria Natalia Lisa, Andrea Brancale, Gwenaëlle André-Leroux, Pedro M. Alzari, Romano Silvestri

\section{- To cite this version:}

Antonio Coluccia, Giuseppe La Regina, Nathalie Barilone, Maria Natalia Lisa, Andrea Brancale, et al.. Structure-based virtual screening to get news scaffold inhibitors of the Ser/Thr Protein Kinase PknB from Mycobacterium tuberculosis. Letters in Drug Design and Discovery, 2016, 13 (10), pp.1012-1018. 10.2174/1570180813666160801162204 . hal-01602403

\section{HAL Id: hal-01602403 https://hal.science/hal-01602403}

Submitted on 27 May 2020

HAL is a multi-disciplinary open access archive for the deposit and dissemination of scientific research documents, whether they are published or not. The documents may come from teaching and research institutions in France or abroad, or from public or private research centers.
L'archive ouverte pluridisciplinaire HAL, est destinée au dépôt et à la diffusion de documents scientifiques de niveau recherche, publiés ou non, émanant des établissements d'enseignement et de recherche français ou étrangers, des laboratoires publics ou privés.

\section{()(1)(2)}

Distributed under a Creative Commons Attribution - ShareAlikel 4.0 International 


\title{
Structure-based Virtual Screening to Get New Scaffold Inhibitors of the Ser/Thr Protein Kinase PknB from Mycobacterium tuberculosis
}

\author{
Antonio Coluccia ${ }^{\mathrm{a}}$, Giuseppe La Regina ${ }^{\mathrm{a}}$, Nathalie Barilone ${ }^{\mathrm{b}}$, María-Natalia Lisa ${ }^{\mathrm{b}}$, Andrea \\ Brancale $^{c}$, Gwenaëlle André-Leroux ${ }^{\mathrm{b}, \mathrm{d}}$, Pedro M. Alzari, ${ }^{\mathrm{b}}$ and Romano Silvestri*a
}

\begin{abstract}
${ }^{a}$ Istituto Pasteur Italia- Fondazione Cenci Bolognetti, Dipartimento di Chimica e Tecnologie del Farmaco, Sapienza Università di Roma, Piazzale Aldo Moro 5, I-00185 Roma, Italy; ${ }^{b}$ Institut Pasteur, Unité de Microbiologie Structurale, CNRS UMR3528, 25 Rue du Dr. Roux, F-75724 Paris, France; ${ }^{c}$ Welsh School of Pharmacy, Cardiff University, King Edward VII Avenue, Cardiff, CF10 3NB, UK; ${ }^{d}$ Inra, Unité Mathématique, Informatique \& Génome, Domaine de Vilvert, 78352 Jouy-en-Josas Cedex, France
\end{abstract}

\author{
A R T I C L E H I S T O R Y \\ Received: July 28, 2015 \\ Revised: June 20, 2016 \\ Accepted: July 27, 2016 \\ DOI: \\ $10.2174 / 1570180813666160801162$
}

\begin{abstract}
In search of new inhibitors of the Ser/Thr protein kinase PknB from Mycobacterium tuberculosis we carried out a structure-based virtual screening study to identify ATP-competitive inhibitors of this enzyme. These studies point out that $\mathrm{N}$-phenylmethylindole-2-carboxamide is a promising scaffold for the development of new PknB inhibitors. We synthesized a small set of analogue compounds to assess the pharmacophore structural requirements and to optimize the inhibitory activity against PknB. This strategy led to the identification of compound 3 , endowed with an $\mathrm{IC}_{50}$ of $20 \mu \mathrm{M}$, which provides a novel scaffold for further improvement of PknB inhibitors.
\end{abstract}

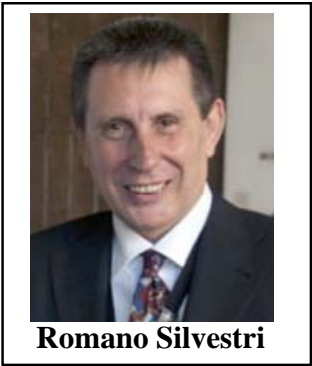

Keywords: Ser, Thr protein kinase PknB, Mycobacterium tuberculosis, Virtual screening, Indole.

\section{INTRODUCTION}

Mycobacterium tuberculosis (Mtb) is the etiological agent of tuberculosis (TB), a major infectious disease that affects millions of people every year. As a bacterial pathogen, Mtb is the second leading cause of death, after the human immuno deficiency virus [1]. The rapid emergence of first- and second-line drug resistant Mtb strains highlights the urgent need for new drugs to treat TB.

Mtb has a complex and dynamic life cycle including replicative and dormant states, highlighting that Mtb bacilli possess efficient signalling systems to sense the surroundings and adapt the physiology accordingly. Mtb codes for eleven eukaryotic-like Ser/Thr Protein Kinases (STPKs) [2]. Among these, the trans-membrane (receptor-like) STPK $\mathrm{PknB}$ is the only Mtb kinase that is upregulated during the exponential growth phase [3-5] upon macrophage infection [6] on the other hand it is down regulated under nutrient starvation in a model of persistent Mtb [7]. Furthermore, PknB has been shown to be essential for Mtb growth [8] being involved in cell-wall biogenesis [9]. Therefore, PknB has been established as a valid target for the design of new anti TB drugs [10-13].

*Address correspondence to Prof.. Romano Silvestri, Dipartimento di Chimica e Tecnologie del Farmaco, Sapienza Università di Roma, Piazzale Aldo Moro 5, I-00185 Roma, Italy; Tel: +39 064991 3800; Fax: +39 06 4991 3993; E-mail: romano.silvestri@uniroma1.it
The PknB kinase domain adopts the typical two-lobed structure found in STPKs. The kinase N-lobe encompasses several $\beta$-sheets and a regulatory $\alpha$-C helix, while the $\mathrm{C}$ terminal lobe is mainly helical. The ATP-binding and protein substrate-binding sites reside at the interface between these two sub-domains $[14,15]$.

Accordingly to the crucial role of $\mathrm{PknB}$ for Mtb proliferation we carried out structure-based virtual screening (VS) studies aimed to identify competitive inhibitor of this enzyme.

\section{RESULT AND DISCUSSION}

\section{Virtual Screening}

We carried out a structure-based virtual VS study using as training set an in-house library of 5000 compounds. The whole training set matched the Lipinski's rules [16]. The crystal structure of PknB solved with the competitive inhibitor mitoxantrone (PDB code: 2FUM) [17] was selected to carried out docking studies. The whole compound library was docked into the PknB ATP binding site using Plants [18] and Autodock [19]. To assess the ability of the docking protocol to discriminate active vs inactive compounds, we separately analysed a test set comprising the co-crystallized mitoxantrone and other PknB inhibitors already reported in literatures for which data about the binding mode were available [12-13]. Both Plants and Autodock provided consistent binding modes for all test set compounds, but the correlation 


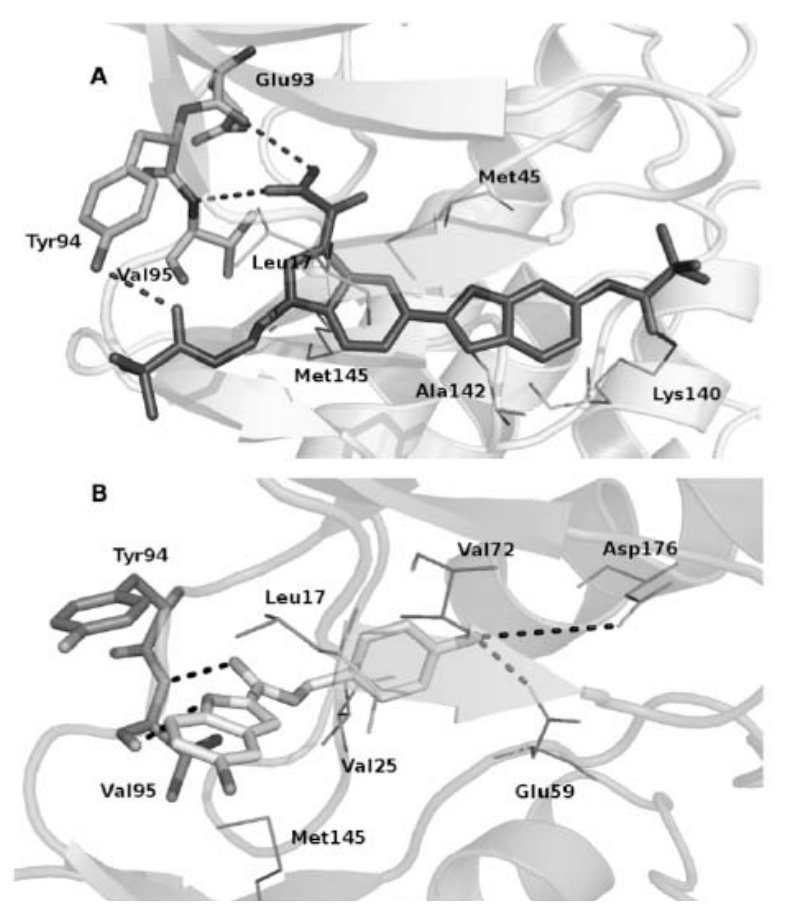

Fig. (1). Binding mode of 1 (Dark grey) Panel A, and 2 (light grey) proposed by Plants. Residues involved in interactions are highlighted as lines, Hinge region residues are reported as stick. Hbonds are reported as dotted lines.

between docking score and in vitro inhibitory activity was unsatisfactory. Hence, we decided to select only those compounds having a RMSD lower than 2, between the best energy poses obtained by Plants and Autodock [20]. This selection filtered the library including over 1000 compounds which were then ranked by number of $\mathrm{H}$-bonds formed with the hinge region. Indeed, it was well known that this interaction was pharmacophoric for kinases inhibitors [21]. The method allowed the identification of a consistent binding mode enhanced by the $\mathrm{H}$-bonds at the hinge region. This was not far from the minimum requirements of the kinases inhibitors [23]. Thus, the best ranked compounds were visual inspected and the most promising compounds were experimentally analysed in order to assess their in vitro inhibitory activity against PknB.

Our procedure has proven to be fruitful thus allowed the identification of compounds $\mathbf{1}$ and $\mathbf{2}$ as new PknB inhibitors. (Table 1) Indeed both derivatives were newly synthesized and evaluated as PknB inhibitors. These compounds inhibited $50 \%$ of PknB kinase activity at the concentration of 100 $\mu \mathrm{M}$ (Table 1). Compound $\mathbf{1}$ was predicted to bind the ATP pocket of $\mathrm{PknB}$ by establishing two $\mathrm{H}$-bonds with residues Glu93 and Val95 in the kinase hinge region, which acts in the positioning of the ATP substrate. The bis-indole moiety is stabilized by hydrophobic interactions with the Leu17 side chains at the N-terminus of the kinase glycine rich loop and Met45, Ala142 and Met145 deep in the ATP binding pocket. An additional key $\mathrm{H}$-bond was highlighted with residue Lys140, located in the catalytic loop of PknG (Fig. 1A). For compound 2 we observed that the indole ring established hydrophobic interactions with residues Leu17 and Met145, the benzyl ring interacted with the side chains of Val25 and Val72. Also, the aromatic amino group formed two H-bonds, one with the conserved residue Glu59 (involved in the locked-in positioning of the regulatory $\alpha \mathrm{C}$ helix through a salt bridge with the catalytic Lys40), and other with residue Asp176 in the DFG motif (Fig. 1B). While compounds 1 and

Table 1. Structure and PknB Inhibition by Compounds 1-9).

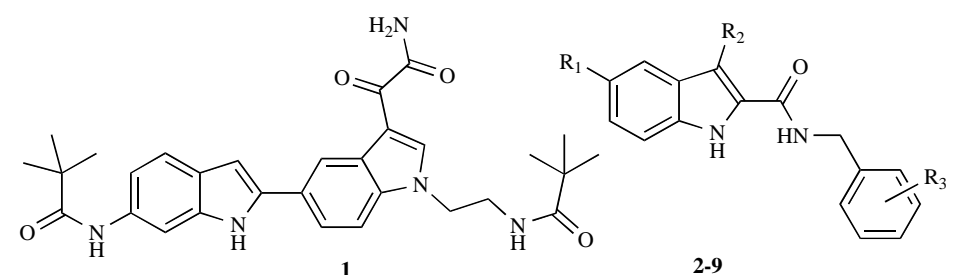

\begin{tabular}{|c|c|c|c|c|}
\hline Compd & $\mathbf{R}_{1}$ & $\mathbf{R}_{2}$ & $\mathbf{R}_{\mathbf{3}}$ & PknB \% Inhibition ${ }^{\text {b) }}$ \\
\hline 1 & - & - & - & 50 \\
\hline 2 & $\mathrm{Cl}$ & $\mathrm{H}$ & 4- $\mathrm{NH}_{2}$ & 50 \\
\hline 3 & $\mathrm{Cl}$ & Phenyl & $3-\mathrm{NH}_{2}$ & 83 \\
\hline 4 & $\mathrm{Cl}$ & $\mathrm{H}$ & $3-\mathrm{Cl}$ & 42 \\
\hline 5 & $\mathrm{Cl}$ & $\mathrm{H}$ & $3-\mathrm{NH}_{2}$ & 20 \\
\hline 6 & $\mathrm{Br}$ & $\mathrm{H}$ & $3-\mathrm{NH}_{2}$ & 20 \\
\hline 7 & $\mathrm{Cl}$ & $\mathrm{H}$ & $4-\mathrm{NO}_{2}$ & 56 \\
\hline 8 & $\mathrm{Cl}$ & $\mathrm{H}$ & $2-\mathrm{NH}_{2}$ & 39 \\
\hline 9 & $\mathrm{Cl}$ & $\mathrm{H}$ & $2-\mathrm{NO}_{2}$ & 53 \\
\hline
\end{tabular}

a) Data are mean values of two to three independent experiments performed in duplicate. Standard deviations correspond to $10 \%$ of the measured value in each case.

b) PknB \% of inhibition; PknB was $30 \mathrm{nM}$, GarA was $20 \mu \mathrm{M}$ and compound was $100 \mu \mathrm{M}$. 


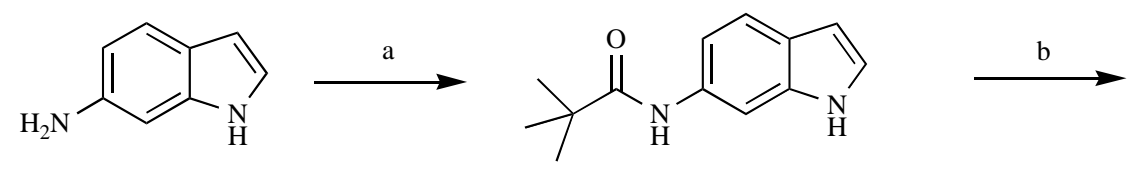

10<smiles>CC(C)(C)C(=O)Nc1ccc2cc(I)[nH]c2c1</smiles>

12
11<smiles>CC(C)(C)C(=O)Nc1ccc2cc(B3OC(C)(C)C(C)(C)O3)[nH]c2c1</smiles>

13

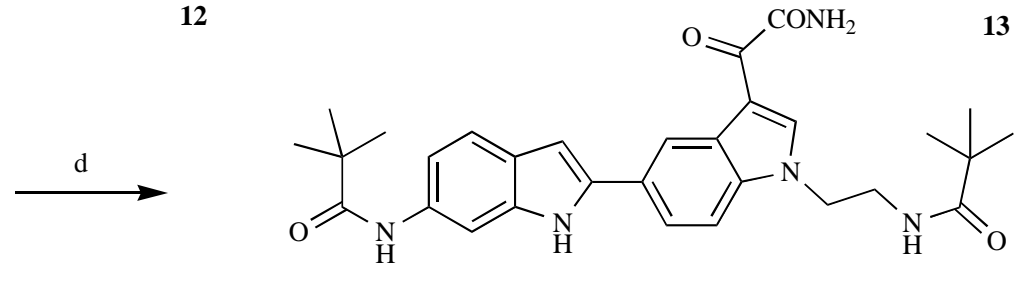

1

Scheme 1. Chemical synthesis of compound 1. Reagents and conditions: (a) pivaloyl chloride, TEA, anhydrous THF, $25{ }^{\circ} \mathrm{C}, 12 \mathrm{~h}, 82 \%$; (b) (i) $\mathrm{n}-\mathrm{BuLi},-78{ }^{\circ} \mathrm{C}$, anhydrous THF, Ar stream, $30 \mathrm{~min}$; (ii) $\mathrm{CO}_{2} \mathrm{~g}, 10 \mathrm{~min}$; (iii) tert-BuLi, $-78{ }^{\circ} \mathrm{C}$, anhydrous $\mathrm{THF}$, Ar stream, $1 \mathrm{~h}$; (iv) $1,2-$ diiodoethane, $-78{ }^{\circ} \mathrm{C}, 1 \mathrm{~h}$, Ar stream, 25\%; (c) pinacol borane, TEA, SPhos, $\mathrm{PdCl}_{2}\left(\mathrm{CH}_{3} \mathrm{CN}\right)_{2}$, toluene, closed vessel, $250 \mathrm{~W}, 20 \mathrm{~min}, \mathrm{Power}-$ MAX, 97\%; (d) 24, $\mathrm{K}_{3} \mathrm{PO}_{4}$, DMF, $\mathrm{Pd}(\mathrm{dppf}) \mathrm{Cl}_{2} \cdot \mathrm{CH}_{2} \mathrm{Cl}_{2}, 60{ }^{\circ} \mathrm{C}, 1 \mathrm{~h}$, Ar stream, $85 \%$.

2 were determined to be equipotent as PknB inhibitors, 2 was selected for further optimization because of its better drug-like properties predicted by QikProp software [22]. Descriptors computed for compound $\mathbf{2}$ were always better than that of compound $\mathbf{1}$ (Table $\mathbf{1 S}$ Supporting Information). Indeed no deviation from Lipinski's rule was accounted. Molecular dynamics (MD) simulations of the PknB-2 complex confirmed the goodness of the H-bonds between the compound and the residues within the kinase hinge region, with a calculated rate of formation $<80 \%$. The hydrophobic contacts remained stable along the trajectory, while the $\mathrm{H}$ bonds involving the compound aromatic amino group disappeared quickly. No significant movements of the complex were observed, suggesting the stabilization of the two kinase lobes upon ligand binding (Figure 1S, Supporting Information).

Subsequently, an in-silico library of compound 2 analogues was generated by superimposition of its binding mode with those of active compounds within the test set Compounds 3-9 (Table 1), which were predicted as the most efficient PknB inhibitors by docking simulations, were synthesized and analyzed in vitro. It is well known that many kinase inhibitors are not selective because they interact with the ATP binding region that has similar geometry amongst the protein kinases. With the aim of assessing the compounds selectivity we firstly identified the kinases (available at protein data bank [24]) with the highest $\mathrm{PknB}$ similarity score, using CPASS [25, 26]. We then docked compounds 29 with the proteins identified in the previous step. CPASS identified three other kinases as the most similar to PknB: MAP1 (64.1\%), GSK-3ß $62.3 \%)$ and Aurora-A (60.8\%). Compounds 2-9 binding poses for MAP1 and GSK-3 $\beta$ were consistent with these observed for $\mathrm{PknB}$, while a different binding mode was observed for Aurora-A. From these results we could speculate that the compounds reported might not be selective toward $\mathrm{PknB}$, following the definition of kinase type I inhibitors [27].

\section{CHEMISTRY}

Synthesis of $\mathbf{1}$ was carried out by a Pd-mediated crosscoupling reaction 13 and 24 (Scheme 1). Carboxamides 4, 17 and 18 were synthesized by coupling the indole-2-carboxylic acid 14-16 with the corresponding amine in the presence of BOP reagent and triethylamine (TEA) in anhydrous DMF at $25{ }^{\circ} \mathrm{C}$ for $12 \mathrm{~h}$ (Scheme 2). Alternatively, an appropriate carboxylic acid was activated by treatment with 1,1'carbonyldiimidazole in anhydrous THF, then treated with the amine to produce compounds 9 or 19. Compound 7 was obtained by reaction of $\mathbf{1 5}$ with 4-nitrobenzylamine hydrochloride in the presence of PyBOP reagent and TEA in anhydrous DMF at $25^{\circ} \mathrm{C}$ for $12 \mathrm{~h}$. Tin(II) chloride reduction of the nitro derivatives 7,9 and $\mathbf{1 7 - 1 9}$ in ethyl acetate at $80{ }^{\circ} \mathrm{C}$ for $3 \mathrm{~h}$ furnished compounds $2, \mathbf{3}, \mathbf{5}, \mathbf{6}$ and $\mathbf{8}$, respectively. Pinacol ester 13 was synthesized starting from 10 that, after reaction with pivaloyl chloride in the presence of TEA in anhydrous THF at $25^{\circ} \mathrm{C}$ for $12 \mathrm{~h}$, was iodinated at position 2 by using the Katritzky method [28] and then transformed into the corresponding boronic ester according to Miyaura reaction conditions [29] under microwave (MW) irradiation (Scheme 1). Reaction of $\mathbf{2 0}$ with chloroacetonitrile in the presence of $\mathrm{NaH}$ in anhydrous DMF at $25{ }^{\circ} \mathrm{C}$ for $12 \mathrm{~h}$ furnished derivative 21, that after reduction with $\mathrm{LiAlH}_{4}$ in anhydrous THF at $50{ }^{\circ} \mathrm{C}$ for $4 \mathrm{~h}$ and subsequent treatment with pivaloyl chloride, as above described, was transformed into 22 (Scheme 3). Compound 22 was treated with oxalyl chloride in anhydrous diethyl ether for $3 \mathrm{~h}$ and then with methanol in the presence of TEA for $5 \mathrm{~h}$ to furnish the methyl 2oxoacetate $\mathbf{2 3}$, that was converted into the corresponding amide 24 by treatment with $28 \% \mathrm{NH} 4 \mathrm{OH}$ in ethanol at 130 


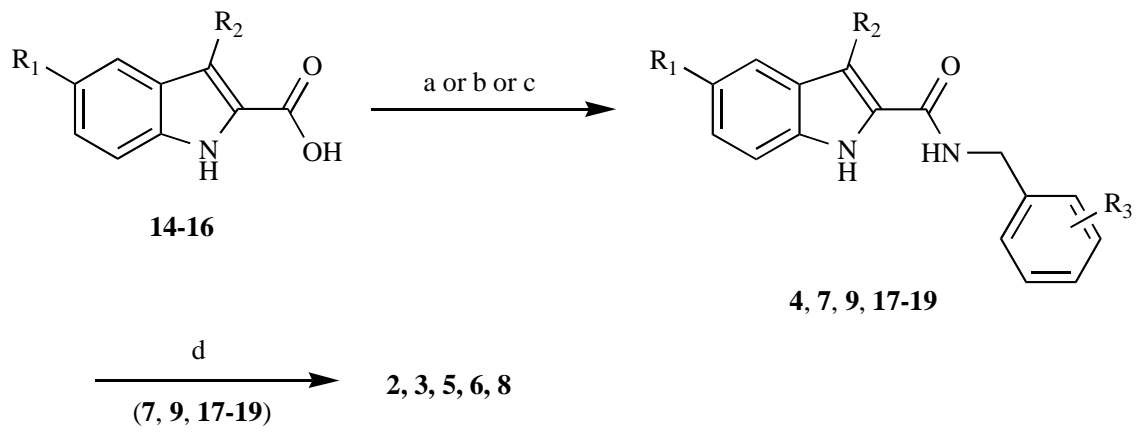

Scheme 2. Chemical synthesis of compounds 2-9 (Table 1); 14: $R_{1}=C l, R_{2}=P h ; 15: R_{1}=C l, R_{2}=H ; 16: R_{1}=B r, R_{2}=H ; 17: R_{1}=C l, R_{2}=$ $\mathrm{H}, \mathrm{R}_{3}=3-\mathrm{NO}_{2} ; 18: \mathrm{R}_{1}=\mathrm{Br}, \mathrm{R}_{2}=\mathrm{H}, \mathrm{R}_{3}=3-\mathrm{NO}_{2} ; 19: \mathrm{R}_{1}=\mathrm{Cl}, \mathrm{R}^{2}=\mathrm{Ph}, \mathrm{R}_{3}=3-\mathrm{NO}_{2}$. Reagents and conditions: (a) (4, 10, 11) amine, BOP reagent, TEA, anhydrous DMF, $25^{\circ} \mathrm{C}, 12 \mathrm{~h}, 47-81 \%$; (b) $(\mathbf{9}, \mathbf{1 2})$ (i) $1,1^{\prime}$-carbonyldiimidazole, anhydrous THF, $25^{\circ} \mathrm{C}, 2 \mathrm{~h}$; (ii) amine, $25^{\circ} \mathrm{C}$, $2 \mathrm{~h}, 42-59 \%$; (c) (7) amine, PyBOP reagent, TEA, anhydrous DMF, $25^{\circ} \mathrm{C}, 12 \mathrm{~h}, 30 \%$; (d) $\mathrm{SnCl}_{2} \cdot 2 \mathrm{HO}, \mathrm{AcOEt}, 80{ }^{\circ} \mathrm{C}, 3 \mathrm{~h}, 54-87 \%$.

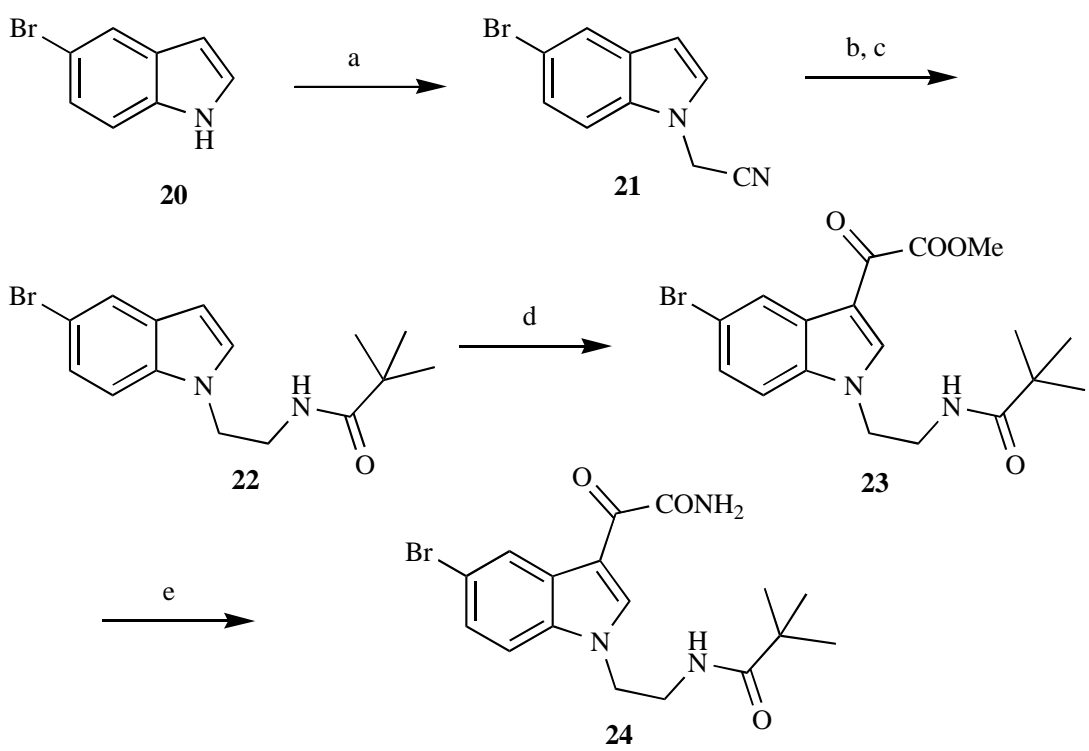

Scheme 3. Chemical synthesis of compound 24. Reagents and conditions: (a) (i) $\mathrm{NaH}$, anhydrous DMF, $25^{\circ} \mathrm{C}, 30$ min; (ii) chloroacetonitrile, $25{ }^{\circ} \mathrm{C}, 12 \mathrm{~h}, 40 \%$; (b) $\mathrm{LiAlH}_{4}$, anhydrous $\mathrm{THF}, 50{ }^{\circ} \mathrm{C}, 4 \mathrm{~h}$, crude product; (c) pivaloyl chloride, TEA, anhydrous THF, $50{ }^{\circ} \mathrm{C}, 12 \mathrm{~h}$, $10 \%$; (d) (i) oxalyl chloride, anhydrous $\mathrm{Et}_{2} \mathrm{O}, 0{ }^{\circ} \mathrm{C}$ for $1.5 \mathrm{~h}$ then $25^{\circ} \mathrm{C}$ for $1.5 \mathrm{~h}$, Ar stream; (ii) $\mathrm{MeOH}$, TEA, $0{ }^{\circ} \mathrm{C}$ for $1 \mathrm{~h}$ then $25{ }^{\circ} \mathrm{C}$ for $4 \mathrm{~h}$, $25 \%$; (e) $28 \% \mathrm{NH}_{4} \mathrm{OH}, \mathrm{EtOH}$, closed vessel, $150 \mathrm{~W}, 130{ }^{\circ} \mathrm{C}, 15 \mathrm{~min}, 73 \%$.

${ }^{\circ} \mathrm{C}(150 \mathrm{~W})$ for $15 \mathrm{~min}$. Carboxylic acid 14 was obtained by bromination of ester 25 with N-bromosuccinimide (NBS) to give the corresponding 3-bromo derivative 26 (Scheme 4). Treatment of $\mathbf{2 6}$ with phenylboronic acid in the presence of $\mathrm{Pd}(\mathrm{dppf}) \mathrm{Cl}_{2} \cdot \mathrm{CH}_{2} \mathrm{Cl}_{2}$ and $\mathrm{Na}_{2} \mathrm{CO}_{3}$ in 1,4-dioxane at $100{ }^{\circ} \mathrm{C}$ for $16 \mathrm{~h}$ provided the 3-phenylindole 27 (Scheme 4). Compound 27 was transformed into the corresponding carboxylic acid 14 by hydrolysis with $\mathrm{LiOH} \cdot \mathrm{H}_{2} \mathrm{O}$ in aqueous THF at $25^{\circ} \mathrm{C}$ for $12 \mathrm{~h}$.

\section{BIOLOGICAL ACTIVITY}

Among the group of compounds 3-9, bearing the $\mathrm{N}$ benzyl at the indole-2-carboxamide, derivative $\mathbf{3}$ inhibited PknB activity by $83 \%$ at a concentration of $100 \mu \mathrm{M}$ and showed an $\mathrm{IC}_{50}$ value of $20 \mu \mathrm{M}$. There was no evident major difference among the substituents at the N-benzyl moiety of 4-9. These compounds inhibited $\mathrm{PknB}$ in the $39-56 \%$ range, although the data are limited. Docking analyses of $\mathbf{3}$ showed the 3-phenyl ring filled a hydrophobic pocket comprising residues Leu17 and Met155, thus ensuring a better stabiliza- tion of the complex within PknB active site (Fig. 2). MD simulations of the complex $\mathrm{PknB}-3$ highlighted a rate of formation near to $100 \%$ for the $\mathrm{H}$-bonds within the kinase hinge region, evidencing an improvement over compound 2. The 3-phenylindole group established contacts with $\mathrm{PknB}$ residues Met145, Met155 and Leu17. The benzyl ring was stabilized by hydrophobic contacts with Val25, no H-bond interactions were observed for the 3-amino group.

\section{MATERIALS AND METHOD}

\subsection{Chemistry}

\section{$N$-(3'-(2-Amino-2-oxoacetyl)-1'-(2-pivalamidoethyl)-1H, I'H-[2,5'-bi-indol]-6-yl)pivalamide (1)}

A mixture of 13 (0.34 g, $0.99 \mathrm{mmol}), 24$ (0.30 g, 7.6 mmol) and $\mathrm{K}_{3} \mathrm{PO}_{4}(0.48 \mathrm{~g}, 2.3 \mathrm{mmol})$ in DMF was degassed for $15 \mathrm{~min}$. $\mathrm{Pd}(\mathrm{dppf}) \mathrm{Cl}_{2} \cdot \mathrm{CH}_{2} \mathrm{Cl}_{2}(0.019 \mathrm{~g}, 0.023 \mathrm{mmol})$ was added and the reaction mixture was heated at $60{ }^{\circ} \mathrm{C}$ for $1 \mathrm{~h}$ under Ar stream, cooled and diluted with water. The organic layer was extracted with ethyl acetate, washed with brine, 

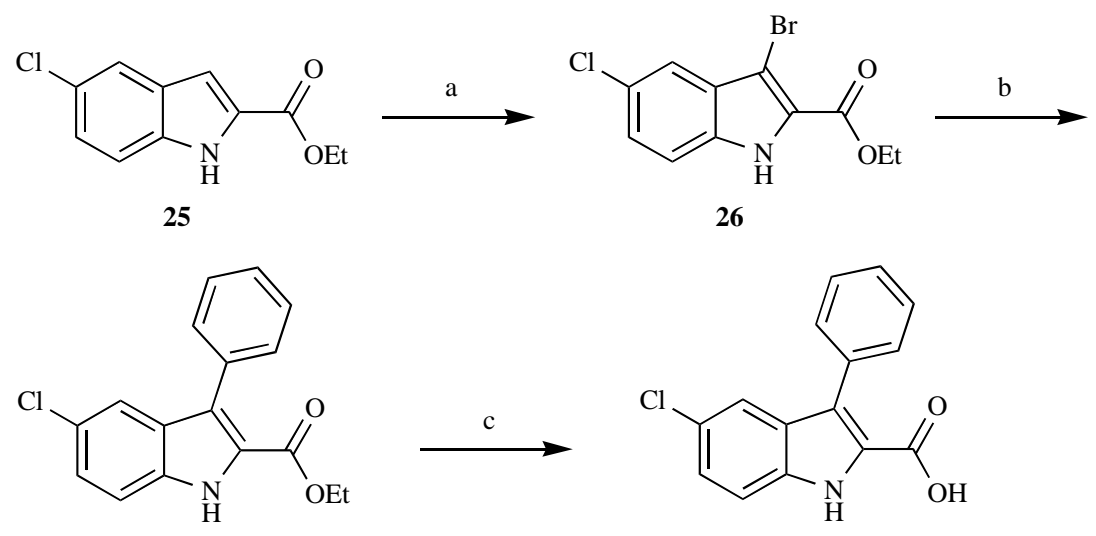

27

14

Scheme 4. Chemical synthesis of compound 14. Reagents and conditions: (a) NBS, anhydrous DMF, $80{ }^{\circ} \mathrm{C}, 3 \mathrm{~h}, 37 \%$; (b) phenylboronic acid, $\mathrm{Pd}(\mathrm{dppf}) \mathrm{Cl}_{2} \cdot \mathrm{CH}_{2} \mathrm{Cl}_{2}, \mathrm{Na}_{2} \mathrm{CO}_{3}, 1,4$-dioxane, $100{ }^{\circ} \mathrm{C}, 16 \mathrm{~h}, 70 \%$; (c) $\mathrm{LiOH} \cdot \mathrm{H}_{2} \mathrm{O}, \mathrm{THF} / \mathrm{H}_{2} \mathrm{O}, 25^{\circ} \mathrm{C}, 12 \mathrm{~h}, 96 \%$.

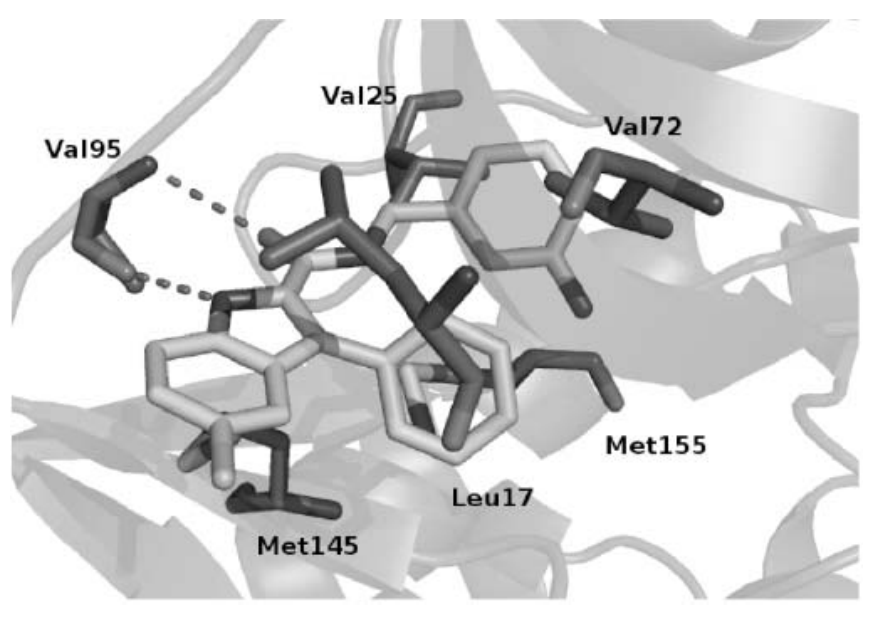

Fig. (2). Snapshot of compound 3 (Light grey) trajectory. Residues involved in interactions are depicted as sticks, the PknB binding site is shown as a cartoon and H-bonds are depicted as dotted lines (black).

dried and filtered. Removal of the solvent gave a residue that was purified by column chromatography (silica gel, ethyl acetate:ethanol $=95: 5$ as eluent) to furnish $1(0.34 \mathrm{~g}, 85 \%)$, $\mathrm{mp} 165-168{ }^{\circ} \mathrm{C}$ (from ethanol). ${ }^{1} \mathrm{H}$ NMR (DMSO-d 6 ): $\delta 0.96-$ $1.00(\mathrm{~m}, 9 \mathrm{H}), 1.22-1.26(\mathrm{~m}, 9 \mathrm{H}), 3.41-3.45(\mathrm{~m}, 2 \mathrm{H}), 4.39-$ $4.41(\mathrm{~m}, 2 \mathrm{H}), 6.75-6.77(\mathrm{~m}, 1 \mathrm{H}), 7.13-7.16(\mathrm{~m}, 1 \mathrm{H}), 7.39-$ $7.80\left(\mathrm{~m}, 4 \mathrm{H} ; 2 \mathrm{H}\right.$ after treatment with $\left.\mathrm{D}_{2} \mathrm{O}\right), 7.92-7.94(\mathrm{~m}$, $1 \mathrm{H}), 8.05$ (br s, disappeared on treatment with $\left.\mathrm{D}_{2} \mathrm{O}, 1 \mathrm{H}\right)$, 8.34-8.36 (m, 1H), 8.67-8.70 (m, 2H), 9.07-9.09 (m, disappeared on treatment with $\left.\mathrm{D}_{2} \mathrm{O}, 1 \mathrm{H}\right), 11.52 \mathrm{ppm}$ (br s, disappeared on treatment with $\left.\mathrm{D}_{2} \mathrm{O}, 1 \mathrm{H}\right)$. IR: $v 1625,2961,3318$ $\mathrm{cm}^{-1}$. Anal. calcd for $\mathrm{C}_{30} \mathrm{H}_{35} \mathrm{~N}_{5} \mathrm{O}_{4}$ (529.64); calcd \%: C 68.03, H 6.66, N 13.22, found \%: C 68.00, H 6.61, N 13.20.

General procedure for the synthesis of compounds 2, 3, 5, 6 and 8. Example. N-(4-Aminobenzyl)-5-chloro-1H-indole-2carboxamide (2)

$\mathrm{SnCl}_{2} \cdot 2 \mathrm{H}_{2} \mathrm{O}(0.203 \mathrm{~g}, 0.9 \mathrm{mmol})$ was added to a solution of $7(0.10 \mathrm{~g}, 0.3 \mathrm{mmol})$ in ethyl acetate $(18.0 \mathrm{~mL})$. The reaction was heated at reflux at $80{ }^{\circ} \mathrm{C}$ for $3 \mathrm{~h}$. After cooling, the reaction mixture was made basic with a saturated aqueous solution of $\mathrm{NaHCO}_{3}$ and filtered. The organic layer was washed with brine, dried and filtered. Removal of the solvent gave a residue that was purified by column chromatography ( silica gel, n-hexane:ethyl acetate $=2: 3$ as eluent) to provide 2 (0.06 g, 66\%), mp 236-240 ${ }^{\circ} \mathrm{C}$ (from ethanol). ${ }^{1} \mathrm{H}$ NMR $\left(\right.$ DMSO-d $_{6}$ ): $\delta$ 4.30-4.31 (d, J = 4.8 Hz, 2H), 4.96 (br s, disappeared on treatment with $\left.\mathrm{D}_{2} \mathrm{O}, 2 \mathrm{H}\right), 6.50-6.52(\mathrm{~d}, \mathrm{~J}=7.6$ $\mathrm{Hz}, 2 \mathrm{H}), 6.97-6.99$ (d, J = 8.0 Hz, 2H), 7.12 (s, 1H), 7.15$7.17(\mathrm{~d}, \mathrm{~J}=8.0 \mathrm{~Hz}, 1 \mathrm{H}), 7.40-7.42(\mathrm{~d}, \mathrm{~J}=8.4,1 \mathrm{H}), 7.67(\mathrm{~s}$, $1 \mathrm{H}), 8.91$ (br s, disappeared on treatment with $\left.\mathrm{D}_{2} \mathrm{O}, 1 \mathrm{H}\right)$, 11.77 ppm (br s, disappeared on treatment with $\mathrm{D}_{2} \mathrm{O}, 1 \mathrm{H}$ ). IR: v 1640, 3219, 3408, cm- ${ }^{1}$. Anal. calcd for $\mathrm{C}_{16} \mathrm{H}_{14} \mathrm{ClN}_{3} \mathrm{O}$ (299.76); calcd \%: C 64.11, H 4.71, N 14.02, Cl 11.83, found $\%$ : C 63.88, H 4.65, N 13.78, Cl 11.55.

\section{N-(3-Aminobenzyl)-5-chloro-3-phenyl-1H-indole-2- carboxamide (3)}

Was synthesized as 2 starting from 19. Yield 54\%, mp 145-150 ${ }^{\circ} \mathrm{C}$ (from ethanol). ${ }^{1} \mathrm{H}$ NMR (DMSO-d ${ }_{6}$ ): $\delta$ 4.234.24 (d, J = 5.8 Hz, 2H), 5.00 (br s, disappeared on treatment with $\left.\mathrm{D}_{2} \mathrm{O}, 2 \mathrm{H}\right), 6.31-6.33(\mathrm{~d}, \mathrm{~J}=7.16 \mathrm{~Hz}, 1 \mathrm{H}), 6.40-6.42(\mathrm{~m}$, $2 \mathrm{H}), 6.89-6.93(\mathrm{t}, \mathrm{J}=8.2 \mathrm{~Hz}, 1 \mathrm{H}), 7.22-7.26(\mathrm{~m}, 1 \mathrm{H}), 7.32-$ $7.36(\mathrm{~m}, 1 \mathrm{H}), 7.42-7.49(\mathrm{~m}, 6 \mathrm{H}), 7.80-7.82(\mathrm{t}, \mathrm{J}=6.1 \mathrm{~Hz}$, disappeared on treatment with $\left.\mathrm{D}_{2} \mathrm{O}, 1 \mathrm{H}\right), 11.96 \mathrm{ppm}(\mathrm{br} \mathrm{s}$, disappeared on treatment with $\left.\mathrm{D}_{2} \mathrm{O}, 1 \mathrm{H}\right)$. IR: $v$ 1649, 3130, $3408 \mathrm{~cm}^{-1}$. Anal. calcd for $\mathrm{C}_{22} \mathrm{H}_{18} \mathrm{ClN}_{3} \mathrm{O}$ (375.86); calcd \%: $\mathrm{C} 70.30, \mathrm{H} 4.83, \mathrm{~N} 11.18, \mathrm{Cl} 9.43$, found $\%: \mathrm{C} 70.12, \mathrm{H}$ 4.78, N 10.95, Cl 9.22.

\subsection{Biological Assays}

\section{PknB Inhibition Assay}

$\mathrm{PknB}$ inhibition assays were carried out in a final volume of $20 \mu \mathrm{L}$, containing $50 \mathrm{mM}$ HEPES, pH 7.0, 1 mM DTT, 1 $\mathrm{mM} \mathrm{MnCl}_{2}$ and $20 \mu \mathrm{M}$ GarA as a substrate. Compounds (100 $\mu \mathrm{M}$ in each case) were initially incubated for $30 \mathrm{~min}$ at $4{ }^{\circ} \mathrm{C}$ with the reaction mixture containing $30 \mathrm{nM} \mathrm{PknB}$. Then, kinase reactions were started by adding $100 \mu \mathrm{M}$ ATP $\left(1 \mu \mathrm{Ci}\right.$ of $\left.\left[\gamma-{ }^{33} \mathrm{P}\right] \mathrm{ATP}\right)$ and were carried out for $30 \mathrm{~min}$ at 37 ${ }^{\circ} \mathrm{C}$. Reactions were stopped by heat inactivation for $4 \mathrm{~min}$ at $95{ }^{\circ} \mathrm{C}$ in the presence of SDS $2 \% \mathrm{w} / \mathrm{v}$ and $6 \mu \mathrm{L}$ were spotted onto P81 paper (phosphocellulose, Whatman). The paper was washed with $1 \%$ v/v phosphoric acid, rinsed with acetone and allowed to dry. Radiolabelled spots were analyzed 
with a phosphoimager (Storm, Molecular Dynamics). Each reaction was performed in duplicates [30].

\subsection{Molecular Modelling}

Hydrogen atoms were added to the crystal structure of PknB (PDB code: 2FUM) by using Molecular Operating Environment (MOE) 2007.09 [31] and minimized, keeping all the heavy atoms fixed until a rmsd gradient of $0.05 \mathrm{kcal}$ mol $^{-1} \AA^{-1}$ was reached. Ligand structures were built with MOE and minimized using the MMFF94 $\mathrm{x}$ force field until a rmsd gradient of $0.05 \mathrm{kcal} \mathrm{mol}^{-1} \AA^{-1}$ was reached. Virtual Screening: The test set was formed by 15 molecules structurally non related selected from already published $\mathrm{PknB}$ inhibitors [11-13]. We selected only molecules for which the binding mode was reported, trying to cover the largest possible range of biological activity. Test set was used to evaluate the docking score ability to discriminate between active and inactive compounds. Docking simulations were performed using PLANTS [18] and Autodock 4.0 [20]. We set up the binding lattice on a sphere of $15 \AA$ radius for PLANTS and on a cubic lattice of $606060 \mathrm{npts}$ for Autodock, centered on the inhibitor mitroxantone. Default settings were used.

Molecular dynamics were performed employing the AMBER 10 suite $[32,33]$ The minimized structure was solvated in a periodic octahedron simulation box, using TIP3P water molecules, providing a minimum of $10 \AA$ of water between the protein surface and any periodic box edge. Ions were added to neutralize the charge of the total system. The water molecules and $\mathrm{Na}^{+}$ions were energy-minimized, keeping the coordinates of the protein-ligand complex fixed $(1,000$ cycles $)$, and then the whole system was minimized $(5,000$ cycles). Next, the entire system was heated and thermalized to $298 \mathrm{~K}$ (5 ps). The simulation was conducted at $298 \mathrm{~K}$, with constant pressure and periodic boundary condition. Shake bond length condition was used $(\mathrm{ntc}=2)$. Compounds were parameterized by Antechamber [34, 35] using BCC charges. Trajectories analysis were carried out by ptraj program [36]. The images in the manuscript were created with PyMOL [37].

\section{CONCLUSION}

We carried out a structure-based VS with the aim to identify new PknB inhibitors. We focused our studies versus the ATP binding site using as filter for the training set docking poses plus H-bonds at the kinase hinge region. We identified $\mathrm{N}$-phenylmethylindole-2-carboxamide derivatives $\mathbf{1}$ and $\mathbf{2}$ as new PknB inhibitors. Additional in silico studies led to design and synthesize a small compound library of compounds 3-9. Compound 3 showed promising inhibition with activity an $\mathrm{IC}_{50}$ value against PknB of $20 \mu \mathrm{M}$. Further investigations are warranted to clarify the structural requirements for further development of this series of anti-PknB compounds

\section{CONFLICT OF INTEREST}

The authors have declared no conflict of interest. These studies were supported by International FIRB code n. RBIN06E9Z8_006 fostering the scientific collaboration between the Pasteur Institute (Paris) and Istituto Pasteur-
Fondazione Cenci Bolognetti (Rome). A. C. also thanks for FIRB for his research fellowship.

\section{ACKNOWLEDGEMENTS}

Declared none.

\section{SUPPLEMENTARY MATERIAL}

Prediction of drug like properties of studied compounds are available at supporting Information. Also rmsd plots of molecular dynamics simulation are available. Supplementary material is available on the publishers Web site along with the published article.

\section{REFERENCES}

[1] Global Tuberculosis 2012, www.who.int/topics/tuberculosis/. (Accessed Feb 17, 2014).

[2] Cole, S.T.; Brosch, R.; Parkhill, J.; Garnier, T.; Churcher, C.; Harris, D.; Gordon, S. V.; Eiglmeier, K.; Gas, S.; Barry, C.E. III; Tekaia, F.; Badcock, K.; Basham, D.; Brown, D.; Chillingworth, T.; Connor, R.; Davies, R.; Devlin, K.; Feltwell, T.; Gentles, S.; Hamlin, N.; Holroyd, S.; Hornsby, T.; Jagels, K.; Krogh, A.; McLean, J.; Moule, S.; Murphy, L.; Oliver, K.; Osborne, J.; Quail, M.A.; Rajandream, M.A; Rogers, J.; Rutter, S.; Seeger, K.; Skelton, J.; Squares, R.; Squares, S.; Sulston, J.E.; Taylor, K.; Whitehead, S.; Barrell. B. G. Deciphering the biology of Mycobacterium tuberculosis from the complete genome sequence Nature., 1998, 393, 537-544.

[3] Av-Gay, Y.; Jamil, S.; Drews S.J. Expression and characterization of the Mycobacterium tuberculosis serine/threonine protein kinase PknB. Infect. Immun., 1999, 67, 676-682.

[4] Sassetti, C.M.; Boyd, D.H.; Rubin E.J. Genes required for mycobacterial growth defined by high density mutagenesis. Mol. Microbiol. 2003, 48, 77-84.

[5] Kang, C.M.; Abbott, D.W.; Park, S.T.; Dascher, C.C.; Cantley, L.C.; Husson, R.N.; The Mycobacterium tuberculosis serine/threonine kinases PknA and PknB: substrate identification and regulation of cell shape. Genes Dev., 2005, 19, 1692-1704.

[6] Singh, A.; Singh, Y.; Pine, R.; Shi, L.; Chandra, R.; Drlica, K. Protein kinase I of Mycobacterium tuberculosis: cellular localization and expression during infection of macrophage-like cells. Tuberculosis, 2006, 86(1):28-33.

[7] Betts, J.C.; Lukey, P.T.; Robb, L.C.; McAdam, R.A.; Duncan, K Evaluation of a nutrient starvation model of Mycobacterium tuberculosis persistence by gene and protein expression profiling. Mol Microbiol., 2002, 43(3):717-31.

[8] Fernandez, P.; Saint-Joanis, B.; Barilone, N.; Jackson, M.; Gicquel, B.; Cole, S. T.; Alzari, P. M. The Ser/Thr protein kinase PknB is essential for sustaining mycobacterial growth. J. Bacteriol. 2006, $188,7778-7784$.

[9] Molle, V.; Kremer, L. Division and cell envelope regulation by Ser/Thr phosphorylation: Mycobacterium shows the way. Mol. Microbiol. 2010, 75, 1064-1772.

[10] Singh, N.K.; Selvam, S. M.; Chakravarthy, P. T-iDT : tool for identification of drug target in bacteria and validation by Mycobacterium tuberculosis. In Silico Biol., 2008, 6, 485-493.

[11] Seal, A.; Yogeeswari, P.; Sriram, D.; OSDD Consortium; Wild, J.D. Enhanced ranking of PknB Inhibitors using data fusion methods. J. Cheminformatics, 2013, 5:2, 2-11.

[12] Lougheed, K.E.A.; Osborne, S.A.; Saxty, B.; Whalley, D.; Chapman, T.; Bouloc, N.; Chugh, J.; Nott, T.J.; Patel, D.; Spivey, V.L.; Kettleborough, C.A.; Bryans, J.S.; Taylor, D.L.; Smerdon, S.J.; Buxton, R.S. Effective inhibitors of the essential kinase PknB and their potential as anti-mycobacterial agents. Tuberculosis, 2011, 91, 277-286.

[13] Chapman, T.; Bouloc, N.; Buxton, R.S.; Chugh,J.; Lougheed, K.E.A.; Osborne, S.; Saxty, B.; Smerdon, S.J.; Taylor, D.L.; Whalleya D. Substituted aminopyrimidine protein kinase B $(\mathrm{PknB})$ in- 
hibitors show activity against Mycobacterium tuberculosis Bioorg Med Chem Lett. 2012, 22, 3349-3353.

[14] Young, T.A.; Delagoutte, B.; Endrizzi, J.A.; Falick, A.M.; Alber, T. Structure of Mycobacterium tuberculosis PknB supports a universal activation mechanism for Ser/ Thr protein kinases. Nat. Struct. Biol., 2003, 10, 168-174.

[15] Ortiz-Lombardia, M.; Pompeo, F.; Boitel, B.; Alzari, P.M. Crystal structure of the catalytic domain of the PknB serine/threonine kinase from Mycobacterium tuberculosis. J. Biol. Chem., 2003, 278, 13094-13100.

[16] Lipinski, C.A.; Lombardo, F.; Dominy, B.W.; Feeney. P.J. Experimental and computational approaches to estimate solubility and permeability in drug discovery and development settings. $A d v$. Drug Deliv. Rev. 2001, 46, 3-26.

[17] Wehenkel, A.; Fernandez, P.; Bellinzoni, M.; Catherinot, V.; Barilone, N.; Labesse, G.; Jackson, M.; Alzari, P.M. The structure of PknB in complex with mitoxantrone, an ATP-competitive inhibitor, suggests a mode of protein kinase regulation in mycobacteria. Febs Lett., 2006, 580, 3018-3022.

[18] Korb, O.; Stutzle, T.; Exner, T. E. PLANTS: Application of ant colony optimization to structure-based drug design. In Ant Colony Optimization and Swarm Intelligence, Proceedings of the $5^{\text {th }}$ International Workshop, ANTS; Dorigo, M.; Gambardella, L. M.; Birattari, M.; Martinoli, A.; Poli, R.; Stutzle, T.; Eds. Lecture Notes in Computer Science, Series 4150; Springer: Berlin, 2006, pp 247258.

[19] Morris, G. M., Huey, R., Lindstrom, W., Sanner, M. F., Belew, R. K., Goodsell, D. S. and Olson, A. J. Autodock4 and AutoDockTools4: automated docking with selective receptor flexiblity. $J$. Comput. Chem. 2009, 16, 2785-2791

[20] Warren, G. L.; Andrews, C. W.; Capelli, A. M.; Clarke, B.; LaLonde, J.; Lambert, M. H.; Lindvall, M.; Nevins, N.; Semus, S.F.; Senger, S.; Tedesco, G.; Wall, I. D.; Woolven, J. M.; Peishoff, C. E.; Head, M.S. A critical assessment of docking programs and scoring functions, J. Med. Chem., 2006, 49, 5912-5931.

[21] Zuccotto, F.; Ardini, E.; Casale, E.; Angiolini, M. Through the "gatekeeper door": exploiting the active kinase conformation $J$. Med. chem 2010, 53, 2681-2694

[22] Jorgensen, W.L.; Duffy, E.M. Prediction of drug solubility from Monte Carlo simulations. Bioorg. Med. Chem. Lett., 2000, 10(11):1155-8.

[23] Roskoski, R.J. Classification of small molecule protein kinase inhibitors based upon the structures of their drug-enzyme complex. Pharm. Research. 2016, 103, 26-48.

[24] http://www.rcsb.org/pdb/home/home.do (Accessed Jun 28, 2015).
Powers, R.; Copeland, J.C.; Germer, K.; Mercier, K.A.; Ramanathan, V.; Revesz P. Comparison of protein active site structures for functional annotation of proteins and drug design. PROTEINS: Struct. Funct. Bioinformatics, 2006, 65,124-135.

[26] Powers, R.; Copeland, J.; Stark, J.; Caprez, A.; Guru, A.; Swanson. D. Searching the protein structure database for ligand-binding site similarities using CPASS v.2 BMC Research Notes, 2011, 4,17-19.

[27] Davis, M.I.; Hunt, J.P.; Herrgard, S.; Ciceri, P.; Wodicka, L.M.; Pallares, G.; Hocker, M.; Treiber, D.K.; Zarrinkar, P.P.; Comprehensive analysis of kinase inhibitor selectivity. Nature Biotechnology, 2011, 29(11):1046-1051.

[28] Katritzky, A.R.; Akutagawa, K. Carbon dioxide: A reagent for the protection of nucleophilic centres and the simultaneous activation of alternative locations to electrophilic attack. Part I. A new synthetic method for the 2-substitution of 1-unsubstituted indoles.Tetrahedron Lett., 1985, 26:5935-5938.

[29] Ishiyama, T.; Murata, M.; Miyaura, N. Palladium(0)-Catalyzed Cross-Coupling Reaction of Alkoxydiboron with Haloarenes: A Direct Procedure for Arylboronic Esters. J. Org. Chem.,1995, 60 (23),7508-7510.

[30] Villarino, R.; Duran, A.; Wehenkel, P.; Fernandez, P.; England, P.; Brodin, S.T.; Cole, U.; Zimny-Arndt, P.R.; Jungblut, C.; Cerveñansky, P.M.; Alzari, P. Proteomic Identification of M. tuberculosis Protein Kinase Substrates: PknB Recruits GarA, a FHA Domaincontaining Protein, Through Activation Loop-mediated Interactions. J. Mol. Biol. 2005, 350, 953-963.

[31] Molecular Operating Environment (MOE) version 2009.10; Chemical Computing Group Inc.: Montreal, Canada; http://www. chemcomp.com/.www.rcsb.org/pdb.

[32] Case, D.A.; Cheatham, T.E. III; Darden, T.; Gohlke, H.; Luo, R.; Merz, K.M. Jr.; Onufriev, A.; Simmerling, C.; Wang, B.; Woods, R. The Amber biomolecular simulation programs. J. Comput. Chem. 2005, 26, 1668-1688.

[33] Meagher, K.L.; Redman, L.T.; Carlson, H.A. Developmentof polyphosphate parameters for use with the AMBER force field. $J$. Comput. Chem. 2003, 24, 1016-1026.

[34] Wang, J.; Wang, W.; Kollman, P. A.; Case, D. A. Automatic atom type and bond type perception in molecular mechanical calculations. J. Mol. Graph. Model. 2006, 25, 247-260.

[35] Wang, J.; Wolf, R. M.; Caldwell, J. W.; Kollman, P. A.; Case, D. A. Development and testing of a general AMBER force field. $J$. Comput. Chem. 2004, 25, 1157-1174.

[36] AmberTools; http://ambermd.org/\#AmberTools

[37] PyMOL version1.2r1; DeLano Scientific LLC: SanCarlos, CA http://www.pymol.org/. 